\title{
Menanamkan Nilai Persatuan Dan Kesatuan Melalui Pembelajaran Sejarah
}

\author{
Kanti Wahyuning Putri \\ Institut Ilmu Kesehatan Strada Indonesia \\ kantiwahyuningputri@gmail.com
}

\begin{abstract}
Abstrak
Kajian ini bertujuan untuk menganalisis peran pendidikan sejarah dalam menanamkan nilai persatuan dan kesatuan. Jenis penelitian kualitatif dengan metode sejarah dan langkah-langkah Heuristik, Kritik Sumber, Interpretasi, dan Historiografi. Hasil kajian menunjukkan bahwa pemahaman sejarah penting sekali dimiliki oleh setiap orang sejak dini supaya mengetahui dan memahami makna dari peristiwa masa lampau sehingga dapat digunakan sebagai landasan sikap dalam menghadapi kenyataan pada masa sekarang, serta menentukan masa yang akan datang. Semua perjuangan yang dilakukan oleh tokoh-tokoh pergerakan nasional ini mencerminkan betapa mulianya akhlak mereka sendiri, yang rela berkorban demi nusa dan bangsanya. Pentingnya sejarah terhadap persoalan kehidupan bersama seperti: nasionalisme, persatuan dan kesatuan, solidaritas dan integritas nasional. Terwujudnya cita-cita suatu masyarakat dan bangsa sangat ditentukan oleh generasi penerus yang mampu memahami sejarah masyarakat dan bangsanya.
\end{abstract}

Kata Kunci: Peran, Pendidikan sejarah, Nilai persatuan dan kesatuan

\section{Latar Belakang}


Mata pelajaran sejarah dalam kurikulum 2013 menyebutkan bahwa mata pelajaran sejarah sebagai mata pelajaran wajib yang harus diperoleh oleh semua warga negara dengan tujuan memberikan pengetahuan tentang bangsa, sikap sebagai bangsa, dan kemampuan penting untuk mengembangkan kehidupan pribadi siswa, masyarakat dan bangsa. Tujuan pembelajaran sejarah ialah untuk menumbuhkan pemahaman siswa terhadap diri sendiri, masyarakat, dan proses terbentuknya bangsa Indonesia melalui sejarah yang panjang dan masih berproses sampai masa kini dan masa yang akan datang. Pembelajaran sejarah dapat membuat siswa mengambil nilainilai dari kehidupan masa lampau untuk direfleksikan terhadap kehidupan zaman sekarang. Pembelajaran sejarah diharapkan mampu membuat siswa bijaksana dalam mengambil setiap keputusan (Umamah et al., 2017:63). Pembelajaran sejarah ialah bidang ilmu yang mempunyai tujuan agar setiap siswa membangun kesadaran tentang pentingnya waktu dan tempat yang merupakan sebuah proses dari masa lampau, masa kini dan masa depan sehingga siswa sadar bahwa dirinya ialah bagian dari bangsa Indonesia yang memiliki rasa bangga dan cinta tanah air yang dapat diimplementasikan dalam berbagai kehidupan baik nasional maupun internasional (Mustika et al., 2017:3). Tujuan pembelajaran sejarah menurut Kasmadi (1996:13) ialah untuk menanamkan semangat kebangsaan, cinta tanah air, bangsa dan negara. Materi pembelajaran sejarah ini mampu mengembangkan potensi siswa untuk lebih mengenal nilai-nilai bangsa yang diperjuangkan pada masa lampau, dipertahankan, dan disesuaikan untuk masa kini dan 
dikembangkan dimasa yang akan datang, dalam sejarah dipaparkan mengenai berbagai peristiwa dan kejadian nyata yang telah terjadi dimasa lampau, bukan hanya karangan fiktif belaka, seperti kegigihan para pejuang melawan penjajah dalam mempertahankan harga diri bangsa.

\section{Kasus/Masalah}

Apa Peran Pendidikan Dalam Menanamkan Nilai Kestuan Dan Kesatuan?

\section{Tinjauan Pustaka}

Kajian ini menggunakan metode sejarah. Metode sejarah ialah suatu periodesasi atau tahapan-tahapan yang ditempuh untuk suatu penelitian sehingga dengan kemampuan yang ada dapat mencapai hakikat sejarah (Usman, 1964:16). Metode sejarah terdiri dari empat langkah yang harus dilakukan yakni heuristik, kritik, interpretasi, dan historiografi. Langkah pertama yakni heruistik. Menurut terminologi heruistik berasal dari bahasa Yunani yaitu heruitiken yakni mengumpulkan, atau menemukan sumber. Sumber atau sumber sejarah (historical source) adalah sejumlah materi yang sudah teridentifikasi (Pranoto, 2010:29). Menurut Pranoto (2010:32) klasifikasi sumber yang digunakan dua. Pertama sumber kebendaan (material source) yakni sumber sejarah yang berupa fisik, dapat dipegang dan dilihat. Kedua sumber immateril atau non kebendaan (immaterial source) yakni sumber sejarah secara fisik tidak dapat dilihat dan dipegang contoh tradisi, kepercayaan, agama, dan lain-lain. Langkah kedua ialah kritik. Tujuan kritik ialah mengetahui keabsahan sumber. Kritik terbagi menjadi dua yakni kritik 
eksternal dan kritik internal. Untuk kritik eksternal ialah usaha mendapatkan otensitas sumber penelitian fisik terhadap aspek luar dari sumber. Otensitas mengacu pada materi sezaman. Jenis-jenis fisik dari materi sumber. Tidak hanya itu saja kritik eksternl perlu diperhatikan kondisi kertas dalam buku. Kemudian kritik internal, yakni kritik yang mengacu kepada kredibilitas sumber, artinya apakah isi dokumen tersebut dipercaya, tidak dimanipulasi, mengandung bias, dikecohkan, dan lain-lain (Pranoto, 2010:36). Langkah ketiga yakni interpretasi. Langkah ini berhubungan dengan kesimpulan sementara dari peneliti mengenai sumber yang akan digunakan dalam proses penelitian. Penulis dalam mengungkap tentang menanamkankan nilai persatuan dan kesatuan melalui pembelajaran sejarah. Langkah keempat ialah historiografi. Pada tahap ini, setelah mendapatklan fakta-fakta sejarah kemudian dirangkai menjadi sebuah rangkaian kajian ilmiah sesuai dengan pembahasan. Maka penulisan ini dapat dirangkai secara kronologis, logis, dan sistematis.

\section{Pembahasan}

\section{Sejarah Pergerakan Nasional}

\section{a. Pengertian Pergerakan Nasional}

Sejarah pergerakan Indonesia (nasional) ialah sejarah yang meliputi aliran yang terdapat dalam sejarah yang dapat menuju pada arah membentuk bangsa dan negara serta nasionalisme di Indonesia. Pengetahuan sejarah pergerakan Indonesia memiliki artian bahwa pemahaman atau menguasai peristiwa-peristiwa penting yang mulai berlangsung pada tahun 1908 sampai 
1945, yang dimulai dengan berdirinya sebuah organisasi pergerakan Indonesia yang bernama organisasi Budi Utomo sampai dibentuknya bangsa Indonesia

\section{b. Latar Belakang Pergerakan Nasional}

Pergerakan nasional yang mewujud sebagai buah protes atas sejumlah penindasan kaum kolonial pada rakyat di Nusantara selama bertahun-tahun, bukanlah peristiwa yang terjadi tiba-tiba dalam fase sesaat. Akan tetapi, melewati serangkaian proses mulai dari bentuknya yang relatif sederhana (tradisional) dengan semangat kedaerahan, hingga pergerakan dalam kategori modern dengan rasa sebangsa sebagai energi penggeraknya, sehingga untuk menjelaskan penyebab timbulnya harus dihubungkaitkan bersama sejumlah prakondisi baik penyebab langsung maupun tidak langsung, dalam banyak literatur, penyebab langsung disebut faktor dalam negeri (internal), sedangkan penyebab tidak langsung dinamakan faktor luar negeri (eksternal).

2. Peran Pendidikan Sejarah Dalam Menanamkan Nilai Persatuan dan Kesatuan

Pendidikan sejarah merupakan pendidikan yang sangat penting untuk mengajarkan kepada siswa akan pentingnya sejarah sebagai pembentuk kepribadian siswa. Sartono Kartodirdjo dalam (Rulianto \& Hartono, 2018:131) berpendapat bahwa dalam rangka pembangunan bangsa, pengajaran sejarah tidak semata mata berfungsi untuk memberikan pengetahuan sejarah sebagai kumpulan informasi fakta sejarah tetapi bertujuan menyadarkan anak didik atau membangkitkan kemampuan berpikir kesejarahannya. Pendidikan sejarah ialah pendidikan yang sanggat penting dalam membentuk siswa mempunyai pemikiran tentang sejarah yang tinggi, maka dalam 
pendidikan sejarah harus mengarah kepada empat tujuan pendidikan sejarah itu sendiri. Menurut Hamid Hasan, dalam (Rulianto \& Hartono, 2018:131) menyatakan bahwa, (1) pendidikan sejarah memberikan materi pendidikan yang mendasar, mendalam dan berdasarkan pengalaman bangsa di masa lalu untuk membangun kesadaran dan pemahaman tentang diri dan bangsanya. (2) Materi pendidikan sejarah ialah materi pendidikan yang khas dalam membangun kemampuan berpikir logis, kritis, analisis, dan kreatif yang sesuai dengan tantangan kehidupan yang dihadapi pada masanya. (3) Pendidikan sejarah menyajikan materi dan contoh keteladanan, kepemimpinan, kepeloporan, sikap dan tindakan manusia dalam kelompoknya yang menyebabkan terjadinya perubahan perubahan dalam kehidupan manusia tersebut. (4) Kehidupan manusia selalu terikat dengan masa lampau karena walaupun hasil tindakan dalam menjawab tantangan bersifat final tetapi hasil dari tindakan tersebut selalu mempunyai pengaruh yang tidak berhenti hanya untuk masanya tetapi berpengaruh terhadap masyarakat tadi dalam menjalankan kehidupan barunya, dan oleh karena peristiwa sejarah menjadi "bank of examples" untuk digunakan dan di sesuaikan sebagai tindakan dalam menghadapi tantangan kehidupan masa kini. Apabila keempat poin di atas dapat terlaksana dengan baik maka terlaksanalah tujuan dari pendidikan sejarah itu.

\section{Kesimpulan}

Pembelajaran sejarah mempunyai peran yang sangat penting di dalam pembentukan watak, sikap dan perkembangan bangsa yang bermakna dalam pembentukan bangsa Indonesia yang memiliki rasa kebangsaan, intelektual, menghargai perjuangan bangsanya dan rasa nasionalisme, karena pembelajaran sejarah mempunyai cakupan materi sebagai berikut: (1) mengandung nilai-nilai kepahlawanan, nilai persatuan dan kesatuan keteladanan, kepeloporan, patriotisme, nasionalisme, dan semangat pantang menyerah yang mendasari proses pembentukan watak dan kepribadian siswa (2) memuat khasanah mengenai peradaban bangsa-bangsa termasuk peradaban bangsa Indonesia; (3) menanamkan kesadaran persatuan dan kesatuan serta solidaritas untuk menjadi pemersatu bangsa dalam menghadapi ancaman disintegrasi; (4) memuat ajaran moral dan kearifan yang berguna dalam mengatasi krisis multidimensi yang dihadapi dalam kehidupan sehari-hari; (5) menanamkan dan mengembangkan sikap bertanggung jawab dalam memelihara keseimbangan dan kelestarian lingkungan hidup.

\section{Daftar Pustaka}


Siyoto, S., \& Sodik, M. A. (2015). Dasar metodologi penelitian. Literasi Media Publishing.

Sodik, M. A., Suprapto, S. I., \& Pangesti, D. (2013). Faktor-Faktor Yang Berhubungan Dengan Pelaksanaan Pelayanan Prima Pegawai Di Rsui Orpeha Tulungagung. STRADA Jurnal IImiah Kesehatan, 2(1), 24-32.

Sodik, M. A., \& Nzilibili, S. M. M. (2017). The Role Of Health Promotion And Family Support With Attitude Of Couples Childbearing Age In Following Family Planning Program In Health. Journal of Global Research in Public Health, 2(2), 82-89.

Setyani, A. T., \& Sodik, M. A. (2018). Pengaruh Merokok Bagi Remaja Terhadap Perilaku dan Pergaulan Sehari-hari.

Attoriq, S., \& Sodik, M. A. (2018). Pencegahan Dan Pengendalian Infeksi Terkait Pelayanan Kesehatan Di Lahan Praktik.

Oktoriani, E. N., Sutrisno, J., Mayasari, E., \& Sodik, M. A. (2018). Analysis of medical record complete flexibility to complete claims of health BPJS RS Baptis Kota Batu. Journal of Global Research in Public Health, 3(1), 46-53.

Sodik, M. A., \& Setyani, A. T. (2018). Effect of Smoking For Teens Against Behavior and Social Interaction.

Siyoto, S., Dwianggimawati, M. S., Sari, D. K., Mufida, R. T., \& Sodik, M. A. (2018). The Effect of Pornography Accessity to Influence Sexual Behavior. Indian Journal of Public Health Research \& Development, 9(12).

Sodik, M. A. (2018). Merokok \& Bahayanya.

Sodik, M. A. (2018, September). Analysis of Improved Attitude of Youth in HIV/AIDS Prevention through the Provision of Health Education with Peer Education. In The 2nd Joint International Conferences (Vol. 2, No. 2, pp. 495-502).

Lim, M. (2021). Menanamkan Nilai Persatuan Dan Kesatuan Melalui Pembelajaran Sejarah. El Tarikh: Journal of History, Culture and Islamic Civilization, 2(1), 117-128.

Yanti, N. K. (2021). NILAI KESATUAN DALAM PEMBELAJARAN SEJARAH (pelaksanaannya dalam kehidupan sehari-hari).

Rispan, R., E Sudrajat, A. (2019). Integrasi Nilai-Nilai Kearifan Lokal Kalosara dalam Pembelajaran Sejarah di SMA sebagai Penguatan Karakter Siswa. Jurnal Pendidikan Sejarah, 8(2), 148-169. 